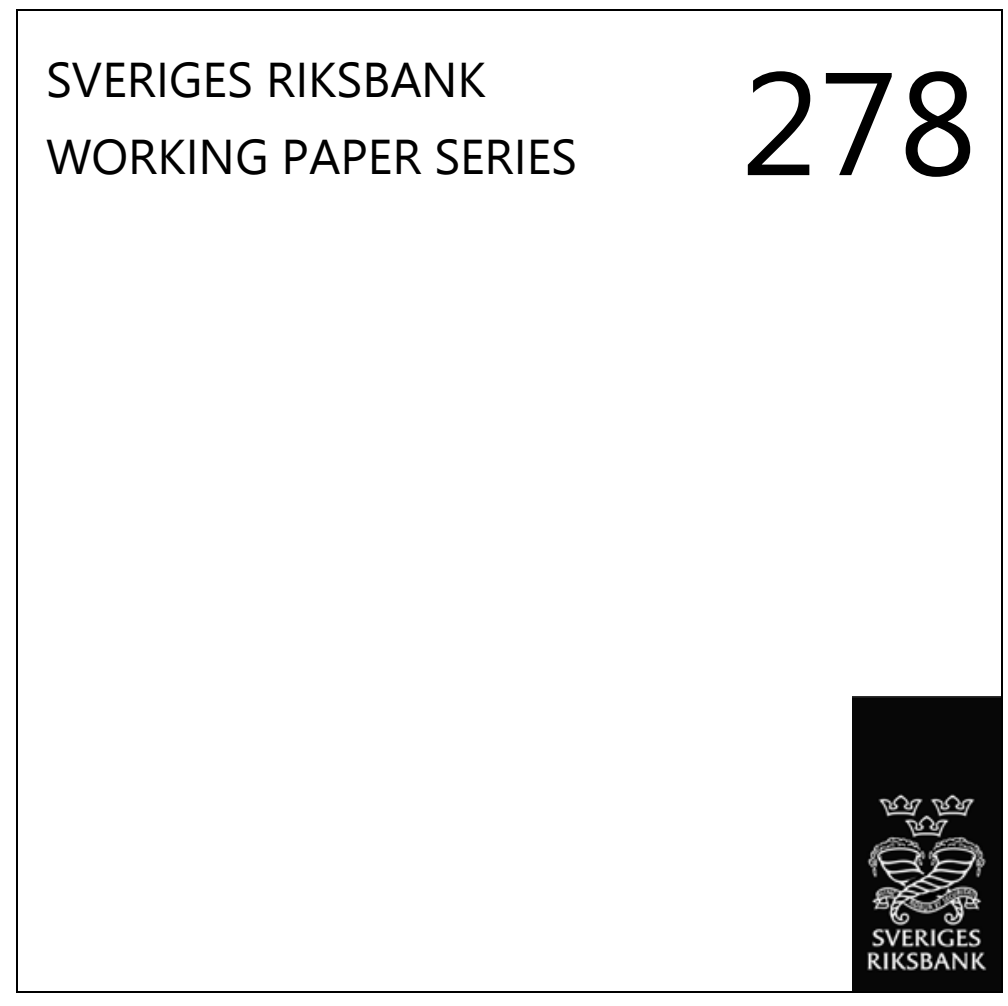

\title{
Distortionary Fiscal Policy and Monetary Policy Goals
}

Klaus Adam and Roberto M. Billi

October 2013 


\section{WORKING PAPERS ARE OBTAINABLE FROM}

Sveriges Riksbank • Information Riksbank • SE-103 37 Stockholm

Fax international: +4687870526

Telephone international: +4687870100

E-mail: info@riksbank.se

The Working Paper series presents reports on matters in the sphere of activities of the Riksbank that are considered to be of interest to a wider public.

The papers are to be regarded as reports on ongoing studies and the authors will be pleased to receive comments.

The views expressed in Working Papers are solely the responsibility of the authors and should not to be interpreted as reflecting the views of the Executive Board of Sveriges Riksbank. 


\title{
Distortionary Fiscal Policy and Monetary Policy Goals*
}

\author{
Klaus Adam ${ }^{\dagger}$ and Roberto M. Billi \\ Sveriges Riksbank Working Paper Series No. 278
}

October 2013

\begin{abstract}
We reconsider the role of an inflation conservative central banker in a setting with distortionary taxation. To do so, we assume monetary and fiscal policy are decided by independent authorities that do not abide to past commitments. If the two authorities make policy decisions simultaneously, inflation conservatism causes fiscal overspending. But if fiscal policy is determined before monetary policy, inflation conservatism imposes fiscal discipline. These results clarify that in our setting the value of inflation conservatism depends crucially on the timing of policy decisions.
\end{abstract}

Keywords: optimal policy, lack of commitment, conservative monetary policy

JEL: E52, E62, E63

\footnotetext{
*We thank seminar participants at the Federal Reserve Bank of Kansas City, the Midwest Macroeconomics Meeting and the SED meeting for helpful comments and discussions. The views expressed herein are solely the responsibility of the authors and should not be interpreted as reflecting the views of the Executive Board of Sveriges Riksbank.

†Mannheim University, Germany and CEPR, United Kingdom (e-mail: adam@uni-mannheim.de)

${ }_{\ddagger}^{\ddagger}$ Sveriges Riksbank, Research Division, Sweden (e-mail: Roberto.Billi@riksbank.se)
} 


\section{Introduction}

The problem of designing institutional frameworks that cope best with discretionary behavior of policymakers has received much attention following the seminal work of Kydland and Prescott (1977) and Barro and Gordon (1983). In particular, to overcome the inflationary bias caused by discretionary conduct of monetary policy, Rogoff (1985) proposed appointing a conservative central banker, who dislikes inflation more than society does. Recently in Adam and Billi (2008) we have shown inflation conservatism à la Rogoff also to be desirable when fiscal policy is endogenous and equally subject to a commitment problem. By introducing distortionary taxation into the setting, in this paper we show that the desirability of inflation conservatism depends crucially on the timing of policy decisions.

We consider, in particular, two policy regimes under discretion. In one, the two authorities decide policy at the same time (simultaneous policy regime). In the other, fiscal policy is determined before monetary policy (fiscal leadership regime). The main result is that inflation conservatism pays off overall, even though excessive concern about inflation may be harmful, depending on the policy regime. In particular, full conservatism, which implies zero inflation in equilibrium, is optimal only in the case of fiscal leadership, arguably the most plausible assumption. Instead, the optimal degree of conservatism in the case of simultaneous policy, though substantially high, is less than full.

The intuition is the following. In the simultaneous policy regime, the fiscal instruments are not observed when the monetary instrument is set. In contrast, under fiscal leadership, the central bank can condition the nominal interest rate on fiscal policy and she does so in a way that depends on her preferences for inflation. Under full conservatism, inflation is completely stabilized at zero. Therefore, a surge in public spending is followed by a strong monetary policy tightening and, as a consequence, the fiscal policy maker correctly perceives the trade-off between public consumption and private consumption, implied by the production function and 
the resource constraint. Then, the Ramsey plan is implemented even if the fiscal policy maker lacks the ability to commit to future policies. The whole mechanism breaks when the central bank moves at the same time as the fiscal authority, since the nominal interest rate cannot be contingent on public expenditure. Rather, the low inflation rate implied by conservatism can be harmful, because it reduces the marginal cost of a further increase of government expenditure, in terms of inflation. It follows that the optimal degree of conservatism under a simultaneous policy regime has to solve a trade-off between high inflation and high public expenditure. The solution to the trade-off is less than full conservatism.

Relative to the existing literature, the paper shows that the presence of distortionary taxation significantly worsens the trade-off between inflation and government expenditure in the simultaneous policy regime. As a consequence, full conservatism is not necessarily optimal in such case. This conclusion partially overturns the result in Adam and Billi (2008). When the government expenditure is financed with lump-sum taxation, as in that paper, full conservatism is always optimal, irrespective of the policy regime. Adam (2011) studies how the level of government debt affects optimal policies under commitment. Finally, Niemann (2011) studies how different levels of government debt affect the desirability of monetary conservatism under discretion in a flexible price economy. If the government issues nominal debt, as in his setting, the high debt tolerance implied by full conservatism can be harmful.

Section 2 describes the model. Section 3 explains the policy regimes. Section 4 presents the policy evaluation. And Section 5 concludes. The Appendix contains technical details.

\section{The model}

We generalize the setting of Adam and Billi (2008) to a case in which public spending is financed with a distortionary income tax. 
There is a continuum of identical households with preferences given by

$$
E_{0} \sum_{t=0}^{\infty} \beta^{t} u\left(c_{t}, h_{t}, g_{t}\right)
$$

where $\beta$ denotes the discount factor. $c_{t}$ denotes consumption of an aggregate good, $h_{t} \in(0,1)$ is labor supply, and $g_{t}$ is public goods provision by the government in the form of an aggregate good. ${ }^{1}$ Each household produces a differentiated intermediate good with a technology linear in $h_{t}$. Demand for that good is $y_{t} d\left(\widetilde{P}_{t} / P_{t}\right)$, where $y_{t}$ is demand for the aggregate good and $\widetilde{P}_{t} / P_{t}$ is the relative price. $d(\cdot)$ satisfies $d(1)=1$ and $d^{\prime}(1)=\eta_{t}$, where $\eta_{t}<-1$ is the price elasticity of demand for the different goods. Thus, $\eta_{t}$ represents a mark-up shock.

The household chooses $\widetilde{P}_{t}$ and then hires labor $\widetilde{h}_{t}$ so satisfy product demand,

$$
z_{t} \widetilde{h}_{t}=y_{t} d\left(\frac{\widetilde{P}_{t}}{P_{t}}\right)
$$

where $z_{t}$ is an aggregate technology shock. The shocks $\eta_{t}$ and $z_{t}$ evolve according to independent $\operatorname{AR}(1)$ stochastic processes with autocorrelation coefficients $\rho_{\eta}$ and $\rho_{z}$ and steady state values $z=1$ and $\eta<-1$. Following Rotemberg (1982), we assume quadratic resource costs of adjusting prices, where $\theta>0$ indexes the degree of price stickiness.

The budget constraint of the household is then

$$
P_{t} c_{t}+B_{t}=R_{t-1} B_{t-1}+P_{t}\left[\frac{\widetilde{P}_{t}}{P_{t}} y_{t} d\left(\frac{\widetilde{P}_{t}}{P_{t}}\right)-w_{t} \widetilde{h}_{t}-\frac{\theta}{2}\left(\frac{\widetilde{P}_{t}}{\widetilde{P}_{t-1}}-1\right)^{2}\right]+P_{t} w_{t} h_{t}\left(1-\tau_{t}\right),
$$

where $R_{t}$ denotes the gross nominal interest rate, $B_{t}$ are nominal bonds paying $R_{t} B_{t}$ in period $t+1, w_{t}$ is the real wage paid in a competitive labor market, and $\tau_{t}$ is a labor income tax. We assume bonds are in zero aggregate net supply. And we rule out Ponzi schemes.

Thus, the household's problem consists of choosing $\left\{c_{t}, h_{t}, \widetilde{h}_{t}, \widetilde{P}_{t}, B_{t}\right\}_{t=0}^{\infty}$ to maximize (1)

\footnotetext{
${ }^{1}$ We assume $u(\cdot)$ is separable and increasing in $c$ and $g$ but decreasing in $h$.
} 
subject to (2) and (3) taking as given $\left\{y_{t}, P_{t}, w_{t}, R_{t}, g_{t}, \tau_{t}\right\}_{t=0}^{\infty}$. The first-order conditions of this problem are (2) and (3) and

$$
\begin{aligned}
u_{h t}= & -u_{c t} w_{t}\left(1-\tau_{t}\right) \\
u_{c t}= & \beta E_{t} \frac{R_{t} u_{c t+1}}{\Pi_{t+1}} \\
0= & u_{c t}\left[y_{t} d\left(r_{t}\right)+r_{t} y_{t} d^{\prime}\left(r_{t}\right)-\frac{w_{t}}{z_{t}} y_{t} d^{\prime}\left(r_{t}\right)-\theta\left(\Pi_{t} \frac{r_{t}}{r_{t-1}}-1\right) \frac{\Pi_{t}}{r_{t-1}}\right] \\
& +\beta \theta E_{t} u_{c t+1}\left(\frac{r_{t+1}}{r_{t}} \Pi_{t+1}-1\right) \frac{r_{t+1}}{r_{t}^{2}} \Pi_{t+1},
\end{aligned}
$$

where $r_{t}=\widetilde{P}_{t} / P_{t}$ denotes the relative price and $\Pi_{t}=P_{t} / P_{t-1}$ is the gross inflation rate. In addition, the usual transversality condition holds.

The government consists of two independent authorities, namely a monetary authority setting $R_{t}$ and a fiscal authority choosing $g_{t}$ in each period $t$. The government is assumed to operate under a balanced budget

$$
\tau_{t} w_{t} h_{t}=g_{t}
$$

We consider a symmetric price-setting equilibrium in which $r_{t}=1$ for all $t$. The first-order conditions of the household's problem can then be condensed into two equilibrium conditions, i.e., a Phillips curve

$$
u_{c t}\left(\Pi_{t}-1\right) \Pi_{t}=\frac{u_{c t} z_{t} h_{t}}{\theta}\left(1+\eta_{t}+\frac{\eta_{t}}{z_{t}}\left(\frac{u_{h t}}{u_{c t}}-\frac{g_{t}}{h_{t}}\right)\right)+\beta E_{t} u_{c t+1}\left(\Pi_{t+1}-1\right) \Pi_{t+1}
$$

and a consumption Euler equation

$$
\frac{u_{c t}}{R_{t}}=\beta E_{t} \frac{u_{c t+1}}{\Pi_{t+1}}
$$

Conveniently, these two equilibrium conditions do not make reference to $\tau_{t}$ and $w_{t} .{ }^{2}$ Thus, ${ }^{2}$ Equations (4) and (5) imply $\tau_{t}=g_{t}\left(g_{t}-h_{t} \frac{u_{h t}}{u_{c t}}\right)^{-1}$ and $w_{t}=\frac{g_{t}}{h_{t}}-\frac{u_{h t}}{u_{c t}}$. 
an equilibrium in the private sector consists of a plan $\left\{c_{t}, h_{t}, \Pi_{t}, R_{t}, g_{t}\right\}_{t=0}^{\infty}$ satisfying (5)-(7) and the market-clearing condition

$$
z_{t} h_{t}=c_{t}+\frac{\theta}{2}\left(\Pi_{t}-1\right)^{2}+g_{t}
$$

\section{The policy regimes}

As a benchmark in the policy evaluation, we use the optimal Ramsey plan, i.e., the optimal commitment policy determined at time zero. The Ramsey planner chooses $\left\{c_{t}, h_{t}, \Pi_{t}, R_{t}, g_{t}\right\}_{t=0}^{\infty}$ to maximize (1) subject to (6)-(8). We assume that the government authorities cannot abide to the Ramsey plan and instead re-optimize in each period. In such a setting, we consider two policy regimes. ${ }^{3}$

Simultaneous policy. In the first regime, the authorities make decisions at the same time in each period. The government in period $t$ has to choose $\left(c_{t}, h_{t}, \Pi_{t}, g_{t}, R_{t}\right)$ to maximize (1) subject to (6)-(8), a fiscal reaction function, a monetary reaction function, and taking as given $\left\{c_{t+j}, h_{t+j}, \Pi_{t+j}, R_{t+j}, g_{t+j}\right\}$ for $j \geq 1$.

In particular, the fiscal reaction function represents the optimal strategy from the point of view of the fiscal authority in period $t$, who takes $R_{t}$ as given. The fiscal authority has to choose $\left(c_{t}, h_{t}, \Pi_{t}, g_{t}\right)$ to maximize (1) subject to (6)-(8) taking as given $\left\{c_{t+j}, h_{t+j}, \Pi_{t+j}, R_{t+j-1}, g_{t+j}\right\}$ for $j \geq 1 .^{4}$ Instead, the monetary reaction function represents the optimal strategy from the vantage point of the monetary authority in period $t$, who takes $g_{t}$ as given. The objective of the monetary authority is assumed to take the form:

$$
E_{t} \sum_{j=0}^{\infty} \beta^{j}\left[(1-\alpha) u\left(c_{t+j}, h_{t+j}, g_{t+j}\right)-\alpha \frac{\left(\Pi_{t+j}-1\right)^{2}}{2}\right]
$$

\footnotetext{
${ }^{3}$ The regimes correspond to the notion of a Markov-perfect equilibrium.

${ }^{4}$ See Appendix A.1 for the calculations.
} 
where $\alpha \in[0,1]$ denotes the degree of inflation conservatism. When $\alpha=1$ the monetary authority cares only about inflation. The monetary authority chooses $\left(c_{t}, h_{t}, \Pi_{t}, R_{t}\right)$ to maximize (9) subject to (6)-(8) taking as given $\left\{c_{t+j}, h_{t+j}, \Pi_{t+j}, R_{t+j}, g_{t+j-1}\right\}$ for $j \geq 1 .^{5}$

Fiscal leadership. In the second regime, the fiscal authority decides before the monetary authority in each period. The government in period $t$ has to choose $\left(c_{t}, h_{t}, \Pi_{t}, g_{t}, R_{t}\right)$ to maximize (1) subject to (6)-(8), the monetary reaction function, and taking as given $\left\{c_{t+j}, h_{t+j}, \Pi_{t+j}, R_{t+j}, g_{t+j}\right\}$ for $j \geq 1$. The monetary reaction function, of course, is the same as in the first regime, because the monetary authority faces the same economic environment in the two regimes.

\section{Policy evaluation}

After calibrating the model, we provide an assessment of the implications of inflation conservatism. We assess the implications on both the steady state and the response to shocks.

\subsection{Calibration}

As in Adam and Billi (2008) household preferences are assumed to take the form:

$$
u\left(c_{t}, h_{t}, g_{t}\right)=\log \left(c_{t}\right)-\omega_{h} \frac{h_{t}^{1+\varphi}}{1+\varphi}+\omega_{g} \log \left(g_{t}\right)
$$

where $\omega_{h}>0, \omega_{g} \geq 0$ and $\varphi \geq 0$ denotes the inverse of the Frisch labor supply elasticity. We set $\beta$ equal to 0.9913 quarterly, to imply a steady-state real interest rate of 3.5 percent annual. $\eta$ is equal to -6 , so that the mark-up over marginal costs is 20 percent. $\theta$ is equal to 17.5 , making Phillips curve (6) consistent with Schmitt-Grohé and Uribe (2004). And $\varphi^{-1}$ is equal to 1 . The weights $\omega_{h}$ and $\omega_{g}$ are chosen such that households in the Ramsey plan work 20

\footnotetext{
${ }^{5}$ See Appendix A.2 for the calculations.
} 
percent of the time and spend 20 percent of output on public goods. ${ }^{6}$ The technology shock has $\rho_{z}$ equal to 0.95 and $\sigma_{z}$ equal to 0.6 percent quarterly, while the mark-up shock has $\rho_{\eta}$ equal to 0.96 and $\sigma_{\eta}$ equal to 2.1 percent quarterly.

\subsection{The implications of inflation conservatism}

Based on the calibrated model, figure 1 shows the effects of inflation conservatism on welfare, measured as the welfare equivalent consumption loss relative to the Ramsey plan. ${ }^{7}$ In the figure, lack of inflation conservatism $(\alpha=0)$ results in a welfare loss of more than 8 percentage points in the two policy regimes. But if we consider inflation conservatism, welfare differs greatly across the two regimes. With simultaneous policy, a value of $\alpha$ slightly below 1 reduces the welfare loss to less than 5 percentage points. However, if $\alpha$ rises to 1 , the welfare loss rises back to about 8 percentage points. With fiscal leadership, by contrast, the welfare loss falls all the way to zero when $\alpha$ rises to 1 . The reason is that, in the fiscal leadership regime, inflation conservatism imposes discipline on public spending.

[Figure 1 about here]

To illustrate the fiscal discipline, figure 2 shows the effects of inflation conservatism on the equilibrium allocation in the two policy regimes and in the Ramsey plan. ${ }^{8}$ If the level of inflation conservatism is moderate $(\alpha=0.7)$, inflation and output (GDP) are high, compared to the Ramsey plan. The high output is achieved via excessive public spending. And public spending crowds out private consumption. With simultaneous policy, raising $\alpha$ results in further crowding out of private consumption. But with fiscal leadership, raising $\alpha$ to 1 eliminates

\footnotetext{
${ }^{6}$ The calculation of the weights can be found in the appendix of Adam (2011), after imposing bonds are in zero aggregate net supply.

${ }^{7}$ Let $u(c, h, g)$ denote the period utility in the Ramsey steady state and $u\left(c^{A}, h^{A}, g^{A}\right)$ the period utility in the steady state of an alternative policy regime. The figure shows the percent fall in consumption $\nu$ making the Ramsey steady state welfare equivalent to the alternative policy regime, i.e., $u(c(1-\nu), h, g)=u\left(c^{A}, h^{A}, g^{A}\right)$.

${ }^{8}$ In the Ramsey steady state $c=0.16, h=0.2, \Pi=1, g=0.04$ and $\tau=0.24$.
} 
the crowding out. Thus, in the fiscal leadership regime, full inflation conservatism recovers the Ramsey allocation.

[Figure 2 about here]

Regarding the dynamics of the economy, figure 3 shows the response after a negative technology shock. The shock size is one standard deviation. On impact, private consumption, public spending and output all fall about 2 percentage points below steady state, while inflation remains at steady state. The response is the same both for the Ramsey plan and for the fiscal leadership regime with full inflation conservatism. At the same time, the response to a mark-up shock is minimal, as figure 4 shows. In fact, the deviation from steady state is less than 0.2 percent and is in the first few quarters only. Overall, in the fiscal leadership regime, full inflation conservatism practically eliminates any volatility in the economy due to technology shocks and mark-up shocks.

[Figure 3 and 4 about here]

\section{Conclusion}

In this paper, we reconsider the role of inflation conservatism in a setting with endogenous fiscal policy and distortionary taxation. The analysis clarifies that the desirability of inflation conservatism depends crucially on the timing of policy decisions. In particular, full conservatism, which implies zero inflation in equilibrium, is optimal only in the case of fiscal leadership, arguably the most plausible case. Still, we do not take into account government debt accumulation. As a consequence, fiscal policy is not allowed to smooth taxes, and the associated distortions, over time. Incorporating these features into the analysis seems an interesting task for future research. 


\section{A Appendix}

This appendix derives the fiscal reaction function and the monetary reaction function. In doing so, let $\gamma_{t}^{j}$ for $j=1$ to 3 denote the Lagrange multipliers on (6)-(8), respectively.

\section{A.1 Fiscal reaction function}

The first-order conditions of the fiscal authority's problem are

$$
\begin{aligned}
c_{t}: & 0=u_{c t}+\gamma_{t}^{1}\left(u_{c c t}\left(\Pi_{t}-1\right) \Pi_{t}-\frac{u_{c c t} z_{t} h_{t}}{\theta}\left(1+\eta_{t}-\frac{\eta_{t}}{z_{t}} \frac{g_{t}}{h_{t}}\right)\right)+\gamma_{t}^{2} \frac{u_{c c t}}{R_{t}}-\gamma_{t}^{3} \\
h_{t}: & 0=u_{h t}-\gamma_{t}^{1} \frac{u_{c t} z_{t}}{\theta}\left(1+\eta_{t}+\frac{\eta_{t}}{z_{t}}\left(\frac{u_{h t}}{u_{c t}}+h_{t} \frac{u_{h h t}}{u_{c t}}\right)\right)+\gamma_{t}^{3} z_{t} \\
\Pi_{t}: & 0=\gamma_{t}^{1} u_{c t}\left(2 \Pi_{t}-1\right)-\gamma_{t}^{3} \theta\left(\Pi_{t}-1\right) \\
g_{t}: & 0=u_{g t}+\gamma_{t}^{1} \frac{u_{c t}}{\theta} \eta_{t}-\gamma_{t}^{3} .
\end{aligned}
$$

Equations (13) and (14) imply

$$
\gamma_{t}^{1}=\frac{u_{g t} \theta\left(\Pi_{t}-1\right)}{u_{c t}\left(2 \Pi_{t}-1-\eta_{t}\left(\Pi_{t}-1\right)\right)}
$$

Using this result and (14) to eliminate $\gamma_{t}^{3}$ in (12) gives the fiscal reaction function

$$
u_{g t}=-\frac{u_{h t}}{z_{t}} \frac{2 \Pi_{t}-1-\eta_{t}\left(\Pi_{t}-1\right)}{2 \Pi_{t}-1-\left(\Pi_{t}-1\right)\left(1+\eta_{t}+\frac{\eta_{t}}{z_{t}}\left(\frac{u_{h t}}{u_{c t}}+h_{t} \frac{u_{h h t}}{u_{c t}}\right)\right)} .
$$




\section{A.2 Monetary reaction function}

The first-order conditions of the monetary authority's problem are

$$
\begin{aligned}
c_{t}: & 0=(1-\alpha) u_{c t}+\gamma_{t}^{1}\left(u_{c c t}\left(\Pi_{t}-1\right) \Pi_{t}-\frac{u_{c c t} z_{t} h_{t}}{\theta}\left(1+\eta_{t}-\frac{\eta_{t}}{z_{t}} \frac{g_{t}}{h_{t}}\right)\right)+\gamma_{t}^{2} \frac{u_{c c t}}{R_{t}}-\gamma_{t}^{3} \\
h_{t}: & 0=(1-\alpha) u_{h t}-\gamma_{t}^{1} \frac{u_{c t} z_{t}}{\theta}\left(1+\eta_{t}+\frac{\eta_{t}}{z_{t}}\left(\frac{u_{h t}}{u_{c t}}+h_{t} \frac{u_{h h t}}{u_{c t}}\right)\right)+\gamma_{t}^{3} z_{t} \\
\Pi_{t}: & 0=\gamma_{t}^{1} u_{c t}\left(2 \Pi_{t}-1\right)-\gamma_{t}^{3} \theta\left(\Pi_{t}-1\right)-\alpha\left(\Pi_{t}-1\right) \\
R_{t}: & 0=-\gamma_{t}^{2} \frac{u_{c t}}{R_{t}^{2}}
\end{aligned}
$$

Equation (18) implies $\gamma_{t}^{2}=0$. While (15)-(17) give, respectively,

$$
\begin{aligned}
& \gamma_{t}^{3}=(1-\alpha) u_{c t}+\gamma_{t}^{1}\left(u_{c c t}\left(\Pi_{t}-1\right) \Pi_{t}-\frac{u_{c c t} z_{t} h_{t}}{\theta}\left(1+\eta_{t}-\frac{\eta_{t}}{z_{t}} \frac{g_{t}}{h_{t}}\right)\right) \\
& \gamma_{t}^{3}=-(1-\alpha) \frac{u_{h t}}{z_{t}}+\gamma_{t}^{1} \frac{u_{c t}}{\theta}\left(1+\eta_{t}+\frac{\eta_{t}}{z_{t}}\left(\frac{u_{h t}}{u_{c t}}+h_{t} \frac{u_{h h t}}{u_{c t}}\right)\right) \\
& \gamma_{t}^{3}=\gamma_{t}^{1} \frac{u_{c t}\left(2 \Pi_{t}-1\right)}{\theta\left(\Pi_{t}-1\right)}-\frac{\alpha}{\theta} .
\end{aligned}
$$

Then (19) and (21) imply

$$
\gamma_{t}^{1}=\frac{\theta\left(1-\alpha+\frac{1}{u_{c t}} \frac{\alpha}{\theta}\right)}{\frac{2 \Pi_{t}-1}{\Pi_{t}-1}-\frac{u_{c c t}}{u_{c t}}\left(\theta\left(\Pi_{t}-1\right) \Pi_{t}-z_{t} h_{t}\left(1+\eta_{t}-\frac{\eta_{t}}{z_{t}} \frac{g_{t}}{h_{t}}\right)\right)} .
$$

While (20) and (21) imply

$$
\gamma_{t}^{1}=\frac{\theta\left(1-\alpha-\frac{z_{t}}{u_{h t}} \frac{\alpha}{\theta}\right)}{\frac{z_{t} u_{c t}}{u_{h t}}\left(1+\eta_{t}-\frac{2 \Pi_{t}-1}{\Pi_{t}-1}+\frac{\eta_{t}}{z_{t}}\left(\frac{u_{h t}}{u_{c t}}+h_{t} \frac{u_{h h t}}{u_{c t}}\right)\right)} .
$$

Equating (22) and (23) gives the monetary reaction function 


$$
\begin{aligned}
& -\frac{z_{t} u_{c t}}{u_{h t}}\left(\eta_{t}\left(\Pi_{t}-1\right)-\Pi_{t}\right)-\left(\Pi_{t}-1\right) \eta_{t}\left(1+h_{t} \frac{u_{h h t}}{u_{h t}}\right) \\
& +\left[2 \Pi_{t}-1-\frac{u_{c c t}}{u_{c t}}\left(\Pi_{t}-1\right)\left(\theta\left(\Pi_{t}-1\right) \Pi_{t}-z_{t} h_{t}\left(1+\eta_{t}-\frac{\eta_{t}}{z_{t}} \frac{g_{t}}{h_{t}}\right)\right)\right] \frac{(1-\alpha) \theta-\alpha \frac{z_{t}}{u_{h t}}}{(1-\alpha) \theta+\alpha \frac{1}{u_{c t}}}=0 .
\end{aligned}
$$

\section{References}

AdAm, K. (2011): "Government Debt and Optimal Monetary and Fiscal Policy," European Economic Review, 55, 57-74.

AdAm, K., AND R. M. Billi (2008): "Monetary Conservatism and Fiscal Policy," Journal of Monetary Economics, 55, 1376-1388.

Barro, R. J., and D. B. Gordon (1983): "A Positive Theory of Monetary Policy in a Natural Rate Model," Journal of Political Economy, 91(4), 589-610.

Kydland, F. E., and E. C. Prescott (1977): "Rules Rather Than Discretion: The Inconsistency of Optimal Plans," Journal of Political Economy, 85(3), 473-491.

Niemann, S. (2011): "Dynamic Monetary-Fiscal Interactions and the Role of Monetary Conservatism," Journal of Monetary Economics, 58, 234-247.

Rogoff, K. (1985): "The Optimal Degree of Commitment to an Intermediate Monetary Target," Quarterly Journal of Economics, 100(4), 1169-1189.

Rotemberg, J. J. (1982): "Sticky Prices in the United States," Journal of Political Economy, 90(6), 1187-1211.

Schmitt-Grohé, S., And M. Uribe (2004): "Optimal Fiscal and Monetary Policy under Sticky Prices," Journal of Economic Theory, 114, 198-230. 
Figure 1: Effect of inflation conservatism on welfare

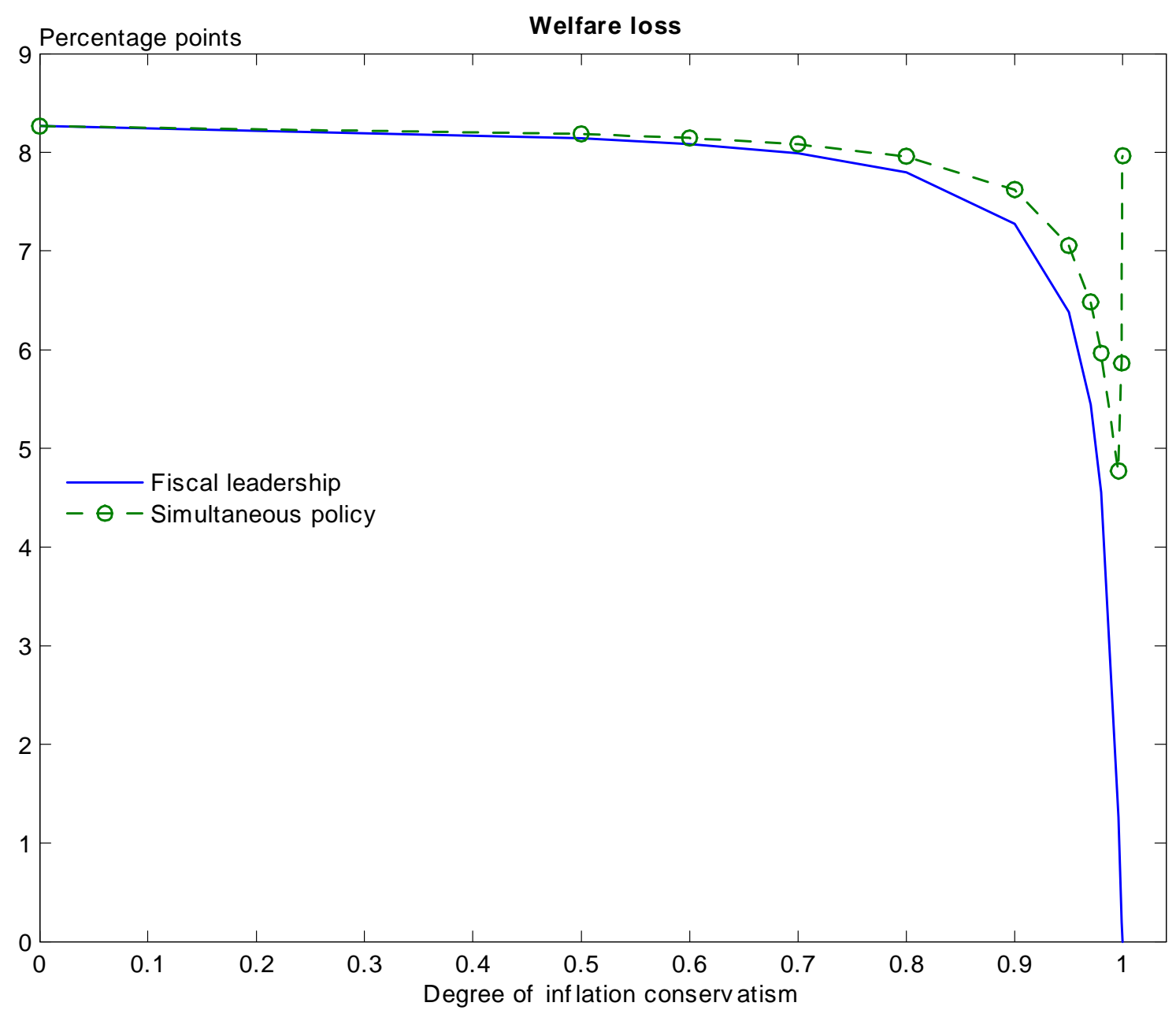

Note: Welfare equivalent consumption loss relative to the Ramsey plan 
Figure 2: Effects of inflation conservatism on the equilibrium allocation
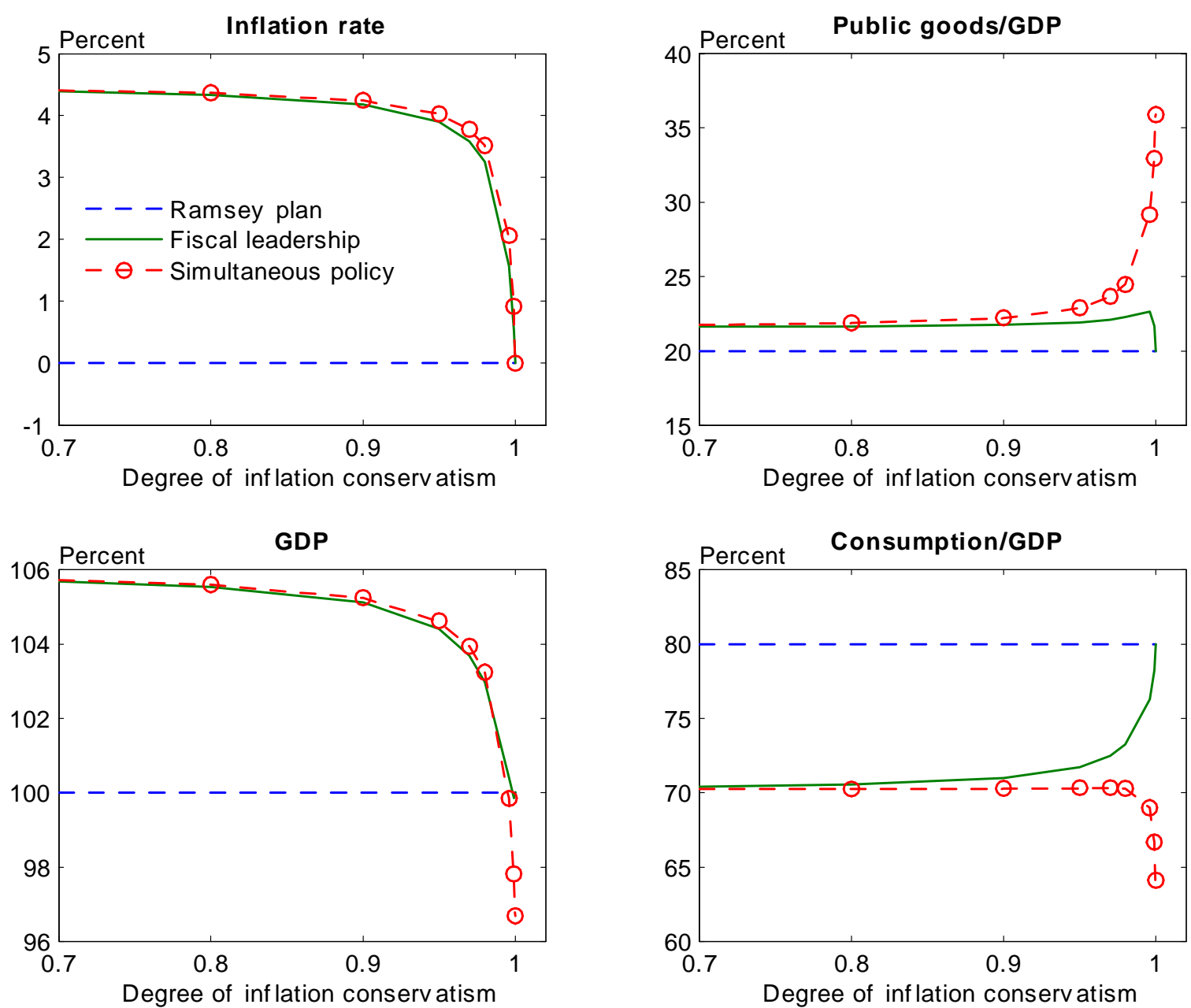

Note: GDP scaled to be 100 in the Ramsey plan 
Figure 3: Response to a technology shock
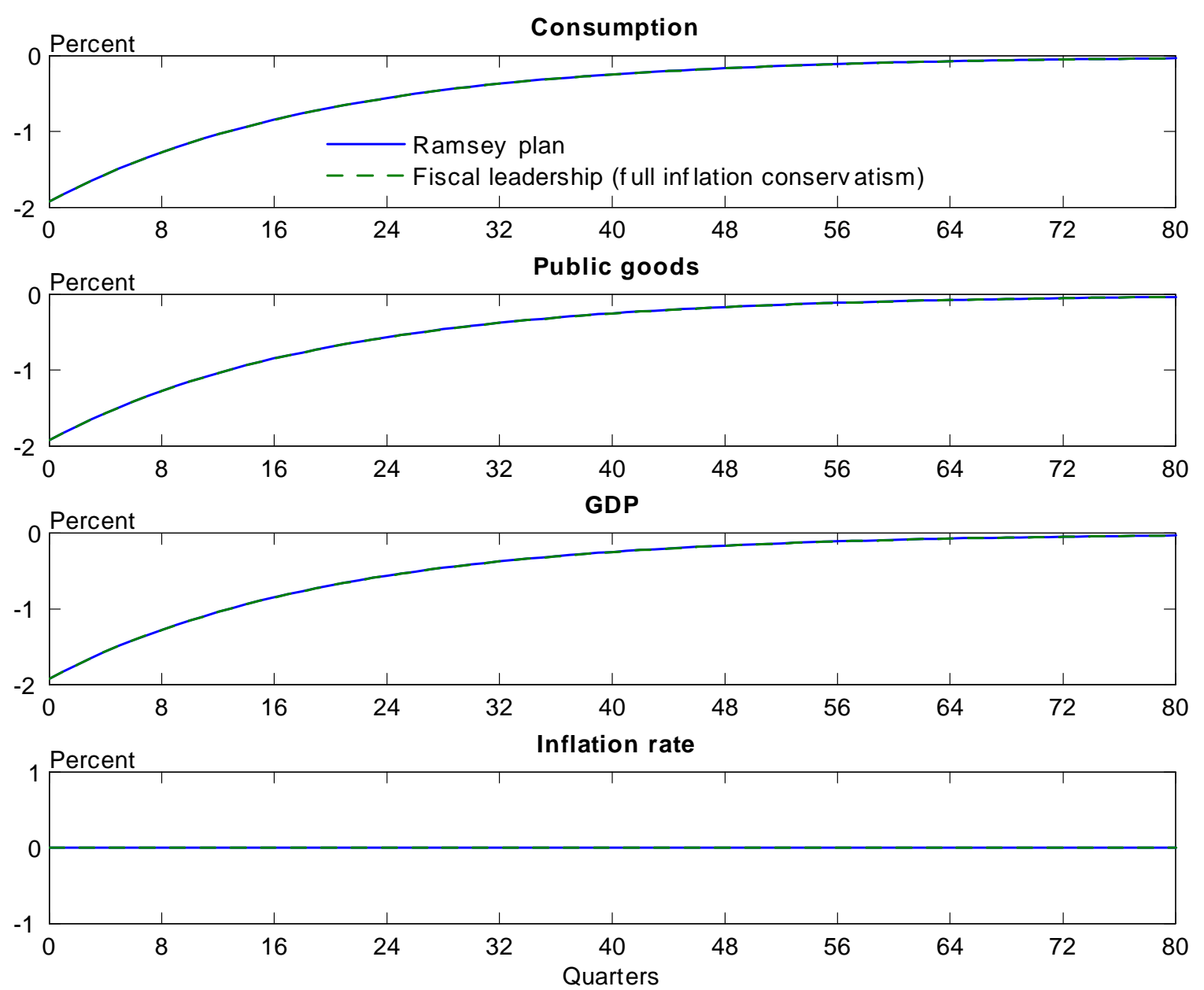

Note: Deviation from steady state after a -1 standard deviation technology shock 
Figure 4: Response to a mark-up shock
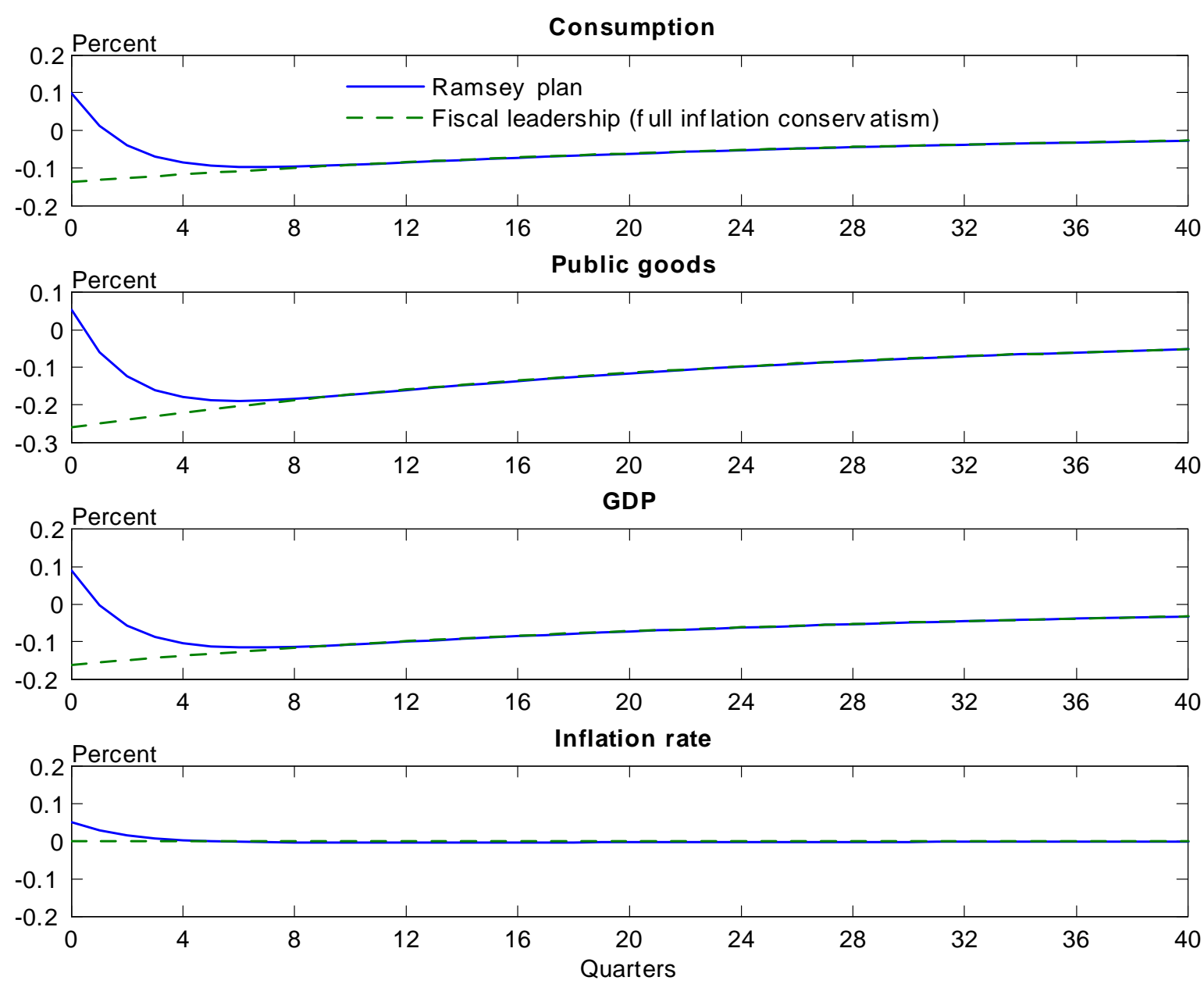

Note: Deviation from steady state after a 1 standard deviation mark-up shock 


\section{Earlier Working Papers:}

For a complete list of Working Papers published by Sveriges Riksbank, see www.riksbank.se

Estimation of an Adaptive Stock Market Model with Heterogeneous Agents

2005:177

by Henrik Amilon

Some Further Evidence on Interest-Rate Smoothing: The Role of Measurement Errors in the Output Gap

2005:178

by Mikael Apel and Per Jansson

Bayesian Estimation of an Open Economy DSGE Model with Incomplete Pass-Through

2005:179

by Malin Adolfson, Stefan Laséen, Jesper Lindé and Mattias Villani

Are Constant Interest Rate Forecasts Modest Interventions? Evidence from an Estimated Open Economy

DSGE Model of the Euro Area

by Malin Adolfson, Stefan Laséen, Jesper Lindé and Mattias Villani

Inference in Vector Autoregressive Models with an Informative Prior on the Steady State

by Mattias Villani

Bank Mergers, Competition and Liquidity

by Elena Carletti, Philipp Hartmann and Giancarlo Spagnolo

Testing Near-Rationality using Detailed Survey Data

by Michael F. Bryan and Stefan Palmqvist

Exploring Interactions between Real Activity and the Financial Stance

by Tor Jacobson, Jesper Lindé and Kasper Roszbach

Two-Sided Network Effects, Bank Interchange Fees, and the Allocation of Fixed Costs by Mats A. Bergman

Trade Deficits in the Baltic States: How Long Will the Party Last?

by Rudolfs Bems and Kristian Jönsson

Real Exchange Rate and Consumption Fluctuations follwing Trade Liberalization

by Kristian Jönsson

Modern Forecasting Models in Action: Improving Macroeconomic Analyses at Central Banks

by Malin Adolfson, Michael K. Andersson, Jesper Lindé, Mattias Villani and Anders Vredin

Bayesian Inference of General Linear Restrictions on the Cointegration Space

2005:182

by Mattias Villani

Forecasting Performance of an Open Economy Dynamic Stochastic General Equilibrium Model

by Malin Adolfson, Stefan Laséen, Jesper Lindé and Mattias Villani

Forecast Combination and Model Averaging using Predictive Measures

by Jana Eklund and Sune Karlsson

Swedish Intervention and the Krona Float, 1993-2002

2005:183

by Owen F. Humpage and Javiera Ragnartz

A Simultaneous Model of the Swedish Krona, the US Dollar and the Euro

2005:184

by Hans Lindblad and Peter Sellin

Testing Theories of Job Creation: Does Supply Create Its Own Demand?

2005:185

by Mikael Carlsson, Stefan Eriksson and Nils Gottfries

Down or Out: Assessing The Welfare Costs of Household Investment Mistakes

by Laurent E. Calvet, John Y. Campbell and Paolo Sodini

Efficient Bayesian Inference for Multiple Change-Point and Mixture Innovation Models

by Paolo Giordani and Robert Kohn

Derivation and Estimation of a New Keynesian Phillips Curve in a Small Open Economy

by Karolina Holmberg

Technology Shocks and the Labour-Input Response: Evidence from Firm-Level Data

2005:187

2005:188

by Mikael Carlsson and Jon Smedsaas

Monetary Policy and Staggered Wage Bargaining when Prices are Sticky

by Mikael Carlsson and Andreas Westermark

The Swedish External Position and the Krona

2005:189

$2005: 190$

2005:191

by Philip R. Lane 
Evaluating Microfoundations for Aggregate Price Rigidities: Evidence from Matched Firm-Level Data on

Monetary Policy Trade-Offs in an Estimated Open-Economy DSGE Model

by Malin Adolfson, Stefan Laséen, Jesper Lindé and Lars E. O. Svensson

Flexible Modeling of Conditional Distributions Using Smooth Mixtures of Asymmetric

Student T Densities

by Feng Li, Mattias Villani and Robert Kohn

Forecasting Macroeconomic Time Series with Locally Adaptive Signal Extraction

Risk Premiums and Macroeconomic Dynamics in a Heterogeneous Agent Model

by Ferre De Graeve, Maarten Dossche, Marina Emiris, Henri Sneessens and Raf Wouters

Picking the Brains of MPC Members

by Mikael Apel, Carl Andreas Claussen and Petra Lennartsdotter

Involuntary Unemployment and the Business Cycle

by Lawrence J. Christiano, Mathias Trabandt and Karl Walentin

Housing collateral and the monetary transmission mechanism

by Karl Walentin and Peter Sellin

The Discursive Dilemma in Monetary Policy

by Carl Andreas Claussen and Øistein Røisland

Monetary Regime Change and Business Cycles

by Luca Sala, Ulf Söderström and Antonella Trigari

Density-Conditional Forecasts in Dynamic Multivariate Models by Michael K. Andersson, Stefan Palmqvist and Daniel F. Waggoner

Anticipated Alternative Policy-Rate Paths in Policy Simulations

The Effects of Endogenuos Firm Exit on Business Cycle Dynamics and Optimal Fiscal Policy 

Sveriges Riksbank

Visiting address: Brunkebergs torg 11

Mail address: se-103 37 Stockholm

Website: www.riksbank.se

SVERIGES Telephone: +46 878700 00, Fax: +46 8210531

RIKSBANK E-mail: registratorn@riksbank.se 